\title{
¿Quechua o Quichua?
}

Esta palabra peruana, cuya trascripción es multiforme en el uso diario de nuestra habla, necesita ser analizada lin guísticamente-en su fonética, su semántica y su trascripción; es decir, vamos a examinarla bien para usarla bien. Solo el conocimiento inteligente de una materia puede garantizarnos su empleo propio y correcto.

Sus Acepciones.-I). La aplicación aborigen o nativa de este vocablo es geográfica: la quebrada templada del este andino se denomina "qheswa". ( I) Más específicamente, "Qheswa" es nombre propio y actual de una quebrada por dondel pasa éfio Velilleod elde Amancay por la hacienda de estégenombre,ellírisdicción del Distrito de Accha-Urinsaya en la Provincia de Paruro (2).

2). Luego, se usa también como término etnológico - para denominar la raza, sus características y costumbres. Así se dice el "pueblo quechua" la "cultura quechua", etc.

3). Por último, se ha universalizado este término como nombre de la lengtia hablada por el Imperio del "Tawantinsuyu", a la cual se denominaba "runa-simi" y los que la

(1) El análisis fonético de esta palabra lo haremos en su debirlo lugar.

(2) Cordero Palacios, O., El Quechua y el Cañari. Cuenca del Ecuador, 1924. Pág. 170. Antonio Raimondi, Itinerario de los Viajes de Raimondi en el Pexú, Boletín de la Sociedad Geográfiea de Lima, T. XXXIII, Lima, Junio 30 de 1917, pág. 7. 
hablan siguen llamándola así. Los primeros cronistas, "lenguaraces" y gramáticos de la conquista y del coloniaje, tradujieron estos dos vocablos runa (hombre), y simi (boca), parafraseándola - "la lengua general de los Incas o del Cusco". La denominación quechúa o quichua nace como una necesidad de economía linguiística en la boca de los españoles. A ellos es debido que el runasimi tenga una denominación adoptada. Mientras tanto, los aborígenes del Cusco no han perdido el nombre de su lenguta; lo mismo, los del Ecuador siguen llamándola inga-simi y los de Bolivia y Argentina Qosqosimi.

Su Fonética.--El sonido inicial de la palabra qhesrua es una velar-aspirada, al que vulgarmente se llama gutural. Este sonido es común en el habla del runasini; p. ej., qhemty (ludir), qhencha (mal agüero), qhelli (sucio). La q representa $e l$ sonido velar-sordo (.3) y la hel aspirado. Es interesante notar aquí que los fonemas velares sordo, aspirado y explosivo $q . q h$ y $q q$, sean directos e invertidos, en todas las palabras del runasimi, se pronuncian en los labios del aborigen con las vocales graves bofuertes yutuncá comblas agudas o débiles. Es por esta Jrazón fonétiealitodos doscque hablan el runasimi y el castellano del Cusco nunca dicen quichua sino quechua; es decir la vocal grave de la palabra qheswa se mantiene en la castellanizada quechua.

$\mathrm{La}$ fricativa-alveolar $s$ se pronuncia sordamente sin la sh suavizada de los dialectos.

Su Trascripción.-Para poder apreciar la trascripción castellana de esta palabra, presentamos aquí un diagrama. Es 'sorprendente notar aquí las caprichosas maneras en la escri-

(3) El uso de la q para representar los sonidos velares está consagrado por los hombres de la ciencia linguística. Phonetic transcription of Indian I anguages. Report of Committeo of American Anthropological Association. Smythsonian Miscellaneous Collections. Vol. 66, Num. 6. City of Washington, Published by the Smythsonian Institution, Sept. 1916. 
tura de esta palabra interesante. A veces un mismo autor es inconsistente en el uso de los signos. Los autores extranjeros y aquellos que han estudiado el runasimi a través de los libros, usan generalmente la vocal aguda $(4, \uparrow, 14)$; así mismo varios de los autores del dialecto ecuatoriano. Esto es explicable por la ausencia del velar en el Ecuador y en el uso del sonido palatal $k$. Mientras tanto en Bolivia y en Argentina persiste la velar $q$ como en el Cusco. Así sucede que los autores del runasimi de estas regiones emplean corrientemente la trascripción fonética y la trascrición castellana con la $e$ $(1,2-3,8,9,12,13,16,17)$. Como ya hemos expuesto en el párrafo referente a la Fonética, el sonido velar quechua rechaza la vocalización aguda. E1 runasimi no dice qiru, Qusqu, qhituy, qqinti, sino qern. (4) Qosqo (Cusco), qhenuy, qqenti (picaflor), etc. Por consiguiente, el que qiuere trascribir fonéticamente el sonido qheswa empleará siempre la $\ell$. Este se refiere al runasimi del Cusco, Bolivia y Argentina. Mientras que los dialectos del Chinchaysuyu y algunos del Ecuador, como no emplean los sonidos velares, la $i$ es común en la escrituralioteca de Letras

Lo que decimosenuel páríafo anterior se refiere al runasimi escrito por los autores de esta lengua. Luego es valioso también mencionar la pronunciación de esta palabra en los labios del que habla el castellano y la "lengua general". El habla popular es el que consagra la fisonomía de la palabra. E1 lingüista y el estudioso sólo investigan y escriben los fenómenos y leyes referentes a las lenguas de una manera objetiva y real.

Decimos que las personas de habla castellana del Perú y Bolivia castellanizan la palabra del runasimi qhestwa en quechua. No hay una persona en el Cusco o Bolivia quien conociendo el runasimi diga quichua.

(4) Qeru, vaso ritual de la cultura quechua, castellanizada, quero. 


\section{- I93 -}

Estos son los hechos, las evidencias tanto fonéticas, documentales y habladas del quechua del Cusco y del quichua de los dialectos del Norte. E1 que quiere referirse al runasimi del Cusco, diga: QUECHUA, y el que habla de algunos dialectos-QUICHUA. Mejor, para que todos estén en armonía, más valiera este consejo casero parafraseado: "Donde quiera que fueres, diga lo que oyeres". Sin embargo, hay que tener presente que el qheswa del Cusco es: QUECHUA.

$$
\begin{aligned}
& \text { J. M. B. FARFÁN. } \\
& \text { Prof. de Quechua. }
\end{aligned}
$$

Lima, I94I. 
Por J. M. B. Farfán

\begin{tabular}{|c|c|c|c|c|c|c|}
\hline $\begin{array}{l}\text { Quechua } \\
\text { (1) }\end{array}$ & $\begin{array}{c}\text { Qqechua } \\
\text { o } \\
\text { Qqichua } \\
(2-3)\end{array}$ & $\begin{array}{l}\text { Quichua } \\
\text { (4) }\end{array}$ & $\begin{array}{c}\text { Quichhua } \\
\text { o } \\
\text { Quichihua } \\
(5-6)\end{array}$ & $\begin{array}{l}\text { Qíchua } \\
\text { (7) }\end{array}$ & $\begin{array}{c}\text { Kjechua } \\
\text { (8) }\end{array}$ & $\begin{array}{c}\text { Keshua } \\
\text { (9) }\end{array}$ \\
\hline $\begin{array}{l}\text { A. de Huerta, } \\
\text { Fr. M. Navarro, } \\
\text { G. Sala, } \\
\text { G. P. Zegarra, } \\
\text { C. Prince, } \\
\text { O. O. Palacios, } \\
\text { M. Toucheux, } \\
\text { J. G. Cosio, } \\
\text { J. Núñez de] } \\
\text { Prado, } \\
\text { J.D. Anchorena }\end{array}$ & $\begin{array}{l}\text { D. G. Holguín, } \\
\text { J. G. Lobato, } \\
\text { E. Sánchez } \\
\text { Melgar. } \\
\\
\end{array}$ & $\begin{array}{l}\text { G. Rubio, } \\
\text { J. F. Nodal, } \\
\text { L. Cordero, } \\
\text { J. Paris, } \\
\text { M. Guzmán, } \\
\text { D. Sto. Tom } \\
\text { D. Markham, } \\
\text { J. Grimm, } \\
\text { F. Dávila, } \\
\text { S. Grigorieff } \\
\text { DIJorge P }\end{array}$ & $\begin{array}{l}\text { A Ricardo, } \\
\text { Huamán Poma } \\
\text { Ca de Le } \\
\text { cinelli Cont }\end{array}$ & $\begin{array}{l}\text { M. A. Mossi } \\
\\
\text { ras } \\
\end{array}$ & M. A. Mossi & J. D. Berrios \\
\hline $\begin{array}{c}\text { Keshua } \\
0 \\
\text { Kishúa } \\
(10-11) \\
\end{array}$ & $\begin{array}{c}\text { Khechua } \\
\text { (12) }\end{array}$ & $\begin{array}{c}\text { Kechua } \\
\text { (13) }\end{array}$ & $\begin{array}{c}\text { Kichua } \\
\text { (14) }\end{array}$ & $\begin{array}{c}\text { Q'eswa } \\
\text { (15) }\end{array}$ & $\begin{array}{c}\text { Keshwa } \\
\text { (16) }\end{array}$ & $\begin{array}{c}\text { Qehshwa } \\
\text { (17) }\end{array}$ \\
\hline $\begin{array}{l}\text { E. W. Midden- } \\
\text { dorf, } \\
\text { Derio. Políglota } \\
\text { Carranza, } \\
\text { P. Patrón, } \\
\text { Prince. }\end{array}$ & M. Argandoña, & $\begin{array}{l}\text { C. Prince, } \\
\text { P. Patrón, } \\
\text { J. Tschudi, } \\
\text { L. Carranza. }\end{array}$ & J. S. Barranea & E. Dijour & Comité 1932 & $\begin{array}{l}\text { Ohukiwanka- } \\
\text { Palacios }\end{array}$ \\
\hline
\end{tabular}

